\title{
Review
}

Molecular

Neuropsychiatry

\section{Variants in Ion Channel Genes Link Phenotypic Features of Bipolar IIIness to Specific Neurobiological Process Domains}

\author{
Yokesh Balaraman Debomoy K. Lahiri John I. Nurnberger \\ Institute of Psychiatric Research, Department of Psychiatry, Neuroscience Research Center, Indiana University \\ School of Medicine, Indianapolis, Ind., USA
}

\section{Key Words}

Bipolar disorder - Genetic load · Phenome - Voltagegated ion channels $\cdot$ Impulse control · Cognitive deficits . Circadian rhythm · Energy disturbances · Mood episodes . Neurobiological process domains - Environmental trigger

\begin{abstract}
Recent advances in genome-wide association studies are pointing towards a major role for voltage-gated ion channels in neuropsychiatric disorders and, in particular, bipolar disorder (BD). The phenotype of BD is complex, with symptoms during mood episodes and deficits persisting between episodes. We have tried to elucidate the common neurobiological mechanisms associated with ion channel signaling in order to provide a new perspective on the clinical symptoms and possible endophenotypes seen in BD patients. We propose a model in which the multiple variants in genes coding for ion channel proteins would perturb motivational circuits, synaptic plasticity, myelination, hypothalamic-pituitary-adrenal axis function, circadian neuronal rhythms, and energy regulation. These changes in neurobiological mechanisms would manifest in endophenotypes of aberrant reward processing, white matter hyperintensities, deficits in executive function, altered frontolimbic connectivity, increased amygdala activity, increased melatonin suppression, decreased REM latency, and aberrant myo-inositol/ATP shuttling. The endophenotypes result in behaviors of poor impulse con-
\end{abstract}

trol, motivational changes, cognitive deficits, abnormal stress response, sleep disturbances, and energy changes involving different neurobiological process domains. The hypothesis is that these disturbances start with altered neural circuitry during development, following which multiple environmental triggers may disrupt the neuronal excitability balance through an activity-dependent molecular process, resulting in clinical mood episodes.

(c) 2015 S. Karger AG, Basel

\section{Introduction}

Bipolar disorder (BD) is a chronic illness with characteristic episodes of high and low activity and energy; these episodes affect the functioning of the individual, resulting in morbidity and mortality. BD has a heritability of about $80 \%$ and often affects multiple family members [1]. Metaanalyses of genome-wide association and gene expression studies have shown that ion channel genes and biological pathways involved in ion channel regulation are associated with BD [2-4].

Genome-wide association studies have shown strong evidence of an association of single nucleotide polymorphisms (SNP) within calcium channel genes with BD. The SNP rs100637 within the calcium channel gene CACNA1C (calcium channel, voltage-dependent, L type, alpha $1 \mathrm{C}$ subunit) is associated at a genome-wide level in

\section{KARGER 125}

C 2015 S. Karger AG, Basel

2296-9209/15/0011-0023\$39.50/0

E-Mail karger@karger.com

www.karger.com/mnp
Yokesh Balaraman, MBBS, MS

Department of Psychiatry, Neuroscience Research Center

Indiana University School of Medicine, 355 W. 16th Street

Indianapolis, IN 46202 (USA)

E-Mail ybalaram@iupui.edu 
mega-analyses incorporating all available $\mathrm{BD}$ genetic datasets (PGC BP Working Group, 2011, 2013). Similarly, SNPs in the calcium channel gene CACNB2 (calcium channel, voltage-dependent, beta 2 subunit) and CACNA1D (calcium channel, voltage-dependent, L type, alpha $1 \mathrm{D}$ subunit), along with CACNA1C, showed genome-wide significance across major psychiatric disorders including BD [5]. SNPs in the calcium channel gene CACNG2 (calcium channel, voltage-dependent, gamma 2 subunit) were also associated with BD in a study of the 22q region in a smaller sample [6], and SNPs in the gene region were also associated with lithium response [7]. Calcium channel genes as a group were associated with BD in gene set analyses by the PGC BP Working Group and the PGC Cross-Disorder Group $[8,9]$.

Another gene that contains SNPs showing strong evidence for an association with $\mathrm{BD}$ is ANK3 [ankyrin 3, node of Ranvier (ankyrin G)] [10-12]. The ANK3 gene codes for the scaffolding protein ankyrin- $G$, which stabilizes the position of sodium and potassium channels in the nerve cell membrane [13].

Evidence is accumulating that SNPs near the potassium channel genes KCNQ2 (potassium voltage-gated channel, KQT-like subfamily, member 2) and KCNQ3 (potassium voltage-gated channel, KQT-like subfamily, member 3) may also be associated with BD [14-17]. Recently, putatively damaging variants in the potassium channel genes $\mathrm{KCNH} 7$ (potassium voltage-gated channel, subfamily $\mathrm{H}$, member 7), KCNG4 (potassium voltage-gated channel, subfamily $\mathrm{G}$, member 4), and KCNB2 (potassium voltage-gated channel, Shab-related subfamily, member 2) have been identified within a large Old Order Amish pedigree [18].

The estimated risk of bipolar illness for SNP rs 10994397 in the ANK3 gene is 1.17, for SNP rs4765913 in the CACNA1C gene 1.13, and for SNP rs11168751 in the $C A C N B 3$ gene 0.84 [19]. The mechanism by which the risk variants (or nearby functional variants) in genes coding for ion channel proteins may alter the neurobiology and neural circuitry in persons with BD is not clearly understood. It could be hypothesized that these variants result in altered excitability, neurotoxicity, synaptic plasticity, and/or neurotransmitter signaling. Several review papers have addressed the neurobiology underlying the ion channel dysfunction in BD [20-22]. In this paper, we have tried to elucidate the common neurobiological mechanisms by which calcium, sodium, and potassium channel abnormalities might contribute to the clinical symptoms, including possible endophenotypes and the overall pathogenesis of $\mathrm{BD}$.

\section{Calcium, ANK3, and Potassium Channel Genes and Proteins}

Ion channels regulate the balance between neuronal excitation and inhibition by conductance of ions in and out of the cell. The resting state membrane potential and the action potential in neurons are due to movement of sodium, potassium, and chloride ions across the membrane. An afterhyperpolarization phase following the action potential in neurons, which prevents hyperexcitability, is achieved by movement of a calcium current through various voltage-dependent calcium channels [23-26] and a $\mathrm{K}^{+}$current through potassium channels [27].

Voltage-gated calcium channels consist of a core alpha 1 subunit, which is the calcium sensor, along with other subunits (beta, alpha 2/delta, and gamma). The alpha 1 subunit consists of five families ( $\mathrm{L}, \mathrm{P} / \mathrm{Q}, \mathrm{N}, \mathrm{R}$, and T type) depending upon the voltage activation characteristics [28]. L-type voltage-dependent calcium channels (LTCC) consist of four members $\left(\mathrm{Ca}_{\mathrm{v}} 1.1,1.2,1.3\right.$, and 1.4) and are present in many tissues throughout the body, including the brain, ventricular myocytes, skeletal muscle, and vascular smooth muscle [29-32]. The CACNA1C gene, which maps to $12 \mathrm{p} 13.3$, encodes an alpha $1 \mathrm{C}$ subunit of an LTCC protein $\left(\mathrm{Ca}_{\mathrm{v}} 1.2\right)$. This is the major subunit in the brain and plays an important role in synaptic plasticity, dendritic structure, learning, and memory [22]. $\mathrm{Ca}_{\mathrm{v}} 1.2$ proteins are concentrated near the cell body, proximal dendrites, and dendritic tree in the neurons, modulating gene transcription and signaling pathways and thereby altering neuronal excitability [22, 33-35]. The CACNA1D gene maps to chromosome $3 \mathrm{p} 14.3$; this gene codes for the alpha 1 delta subunit of the L-type voltagegated calcium channel $\mathrm{Ca}_{\mathrm{v}} 1.3$ [30]. The CACNA1A gene (calcium channel, voltage-dependent, $\mathrm{P} / \mathrm{Q}$ type, alpha $1 \mathrm{~A}$ subunit) maps to chromosome $19 \mathrm{p} 13$; it codes for the voltage-dependent alpha $1 \mathrm{~A}$ subunit $\mathrm{P} / \mathrm{Q}$ calcium channel $\mathrm{Ca}_{\mathrm{v}} 2.1$ protein. $\mathrm{Ca}_{\mathrm{v}} 2.1$ is expressed predominantly in the nervous system, and mutations in CACNA1A have been associated with familial hemiplegic migraines [36]. The CACNA1B gene maps to chromosome 9q34; it codes for the voltage-dependent alpha $1 \mathrm{~B}$ subunit of the $\mathrm{N}$-type calcium channel $\mathrm{Ca}_{\mathrm{v}} 2.2$ protein and controls the channel activity of the alpha 1 subunit [37]. The CACNB1-4 genes code for four beta subunits of the voltage-dependent calcium channel [38]. The beta subunit is essential for the stabilization of the alpha 1 subunit and can control the activation and inactivation of other voltage-gated calcium channel subunits [39-41]. The CACNG1-8 genes code for eight gamma subunits of voltage-gated calcium 
channels [42]. The gamma 2, 3, 4, and 8 subunits are called transmembrane AMPA receptor regulatory proteins, which are involved in the trafficking of AMPA receptors to the membrane in the synapse [43].

The ANK3 gene maps to 10q21; it codes for two 480and $270-\mathrm{kDa}$ isoforms of a brain-specific protein called ankyrin-G, with the isoforms localized at the axon initial segment and at the nodes of Ranvier in the neuron, respectively [44]. Ankyrin-G binds to sodium and potassium channels at the axon initial segment and nodes of Ranvier and is essential for clustering of sodium channels [45-47] and potassium channels [48, 49].

The potassium channels fall into four families consisting of voltage-gated $\left(\mathrm{K}_{\mathrm{v}}\right)$, inward-rectifying $\left(\mathrm{K}_{\mathrm{ir}}\right)$, calcium-activated $\left(\mathrm{K}_{\mathrm{Ca}}\right)$, and tandem pore domain $\left(\mathrm{K}_{2 \mathrm{p}}\right.$ and 4T) channels [50]. The potassium channel genes KCNQ2, which maps to $20 \mathrm{q} 13.3$, and $K C N Q 3$, which maps to $8 \mathrm{q} 24$, code for the voltage-gated potassium channel proteins termed $\mathrm{K}_{\mathrm{v}} 7.2$ and 7.3. They form an integral part of the $M$ potassium channel, slowly activating and deactivating the $M$ current that regulates neuronal excitability $[51,52]$. The KCNB2 gene, which maps to $8 \mathrm{q} 13.2$, codes for the potassium channel protein $\mathrm{K}_{\mathrm{v}} 2.2$, which is found in axon initial segments and dendrites of the medial nucleus of trapezoid body neurons and cortical pyramidal neurons and plays a role in regulating action potential amplitude and firing $[53,54]$. The $\mathrm{KCNH} 7$ gene, which maps to 2q24.2, codes for the voltage-gated subfamily member $\mathrm{H}$ subunit of potassium channel $\mathrm{K}_{\mathrm{v}} 11.3$. This is present primarily in the nervous system and plays an important role in the regulation of the membrane potential and neuronal excitability [55].

\section{The Phenome of BD from the Ion Channel Perspective}

A phenome represents the set of all phenotypes expressed at various levels, including manifestations at the cell, tissue, and organic level, representing the sum total of phenotypic traits. BD patients exhibit mood episodes that include poor impulse control, cognitive deficits, abnormal stress response, sleep disturbances, and fluctuations in energy level, along with mood states of mania, depression, and/or irritability including rapid switches from mania to depression and depression to mania; these symptoms and signs represent the phenome at the organic level. The clinical symptoms seen in bipolar illness patients could be deconstructed into neurobiological process domains of impulse control/motivational reward

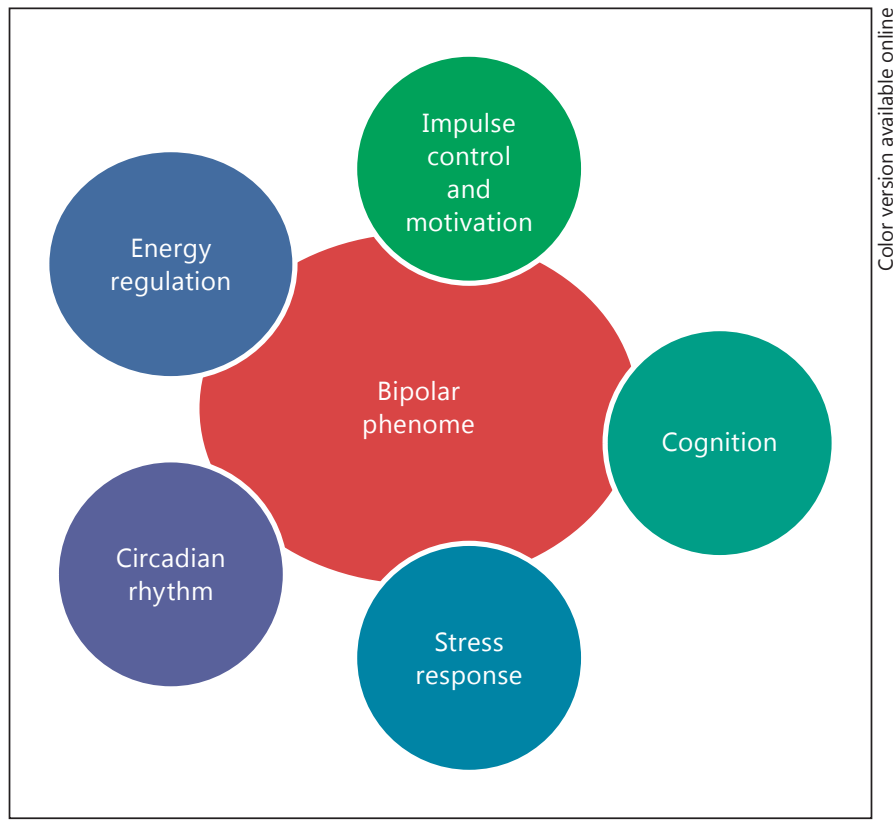

Fig. 1. Deconstructing bipolar symptoms into neurobiological process domains.

processing, cognition, stress response, circadian rhythm, energy regulation, and metabolism, representing the 'bipolar phenome' (fig. 1). Some abnormalities in the BD phenome may represent endophenotypes. Rieder and Gershon [56] proposed that a genetic vulnerability marker should be heritable, associated with illness, state independent, and cosegregate with illness within families. Gottesman and Gould [57] first used the term 'endophenotype' to describe such biomarkers. Besides the criteria above, they proposed that the endophenotype should occur with a higher incidence in nonaffected family members than in the general population. Possible endophenotypes in $\mathrm{BD}$ have been described in several reviews $[58,59]$.

We are suggesting that the following characteristics related to BD may be candidate endophenotypes: motivational reward processing, white matter hyperintensities, deficits in executive function, altered frontolimbic connectivity, aberrant amygdala activity, melatonin suppression, REM latency, and myo-inositol/ATP shuttling [58, $60]$. We posit that these are present even before the mood episodes emerge and that the genetic load of SNPs, structural variants, and sequence variants affecting ion channel genes contributes to those deficits starting early in development. Below, we elucidate the neurobiological mechanisms underlying calcium, sodium, and potassium 
ion channel signaling and relate these mechanisms to the phenome, including possible endophenotypes and the clinical symptomatology of $\mathrm{BD}$.

Impulse Control and Motivational Reward Processing Patients with BD exhibit poor impulse control, resulting in impulsive risk-taking behaviors and addiction to substances [61]. Clinical studies using the Barratt Impulsiveness Scale (BIS) have shown that impulsivity is present not only during affective states but also in the euthymic state $[62,63]$, and that it also occurs in unaffected siblings [64]. Lombardo et al. [64] studied impulsivity using the BIS-11 in euthymic bipolar patients, unaffected relatives, and healthy controls. The BIS-11 scores were higher in unaffected relatives during motor and nonplanning tasks than in controls. Euthymic bipolar patients showed a higher score in all subgroups of attention, motor, and nonplanning tasks compared to unaffected relatives and controls, indicating that poor impulse control might be an endophenotype of bipolar illness. A study involving the Iowa Gambling Task in bipolar patients has shown that their performance was significantly impaired, with patients making erratic choices both in euthymic and ill states [65]. Motivational reward-related behavioral tasks and functional imaging studies have shown dysfunctional reward learning in BD patients irrespective of their state $[66,67]$. Functional MRI (fMRI) studies in unaffected relatives showed an increased activation of the orbitofrontal cortex and amygdala in response to reward-related stimuli [68].

How may ion channel dysfunction contribute to poor impulse control and motivational reward processing? Mesolimbic and mesocortical dopaminergic circuits have been implicated as key networks in impulse control and motivational reward processing $[69,70]$. The neurobiological mechanisms that regulate dopaminergic neuron firing and dopamine release in mesolimbic and mesocortical circuits would lead to poor impulse control and motivational reward processing. Ferrari et al. [71] have shown that mouse pup brains show spontaneous bursting in midbrain dopamine neurons (which send axonal projections to the striatum) at the E16 embryonic stage; this bursting is regulated by L- and N-type calcium channels, which release dopamine based on stimulation in a calcium-dependent manner. Velazquez-Ulloa et al. [72] have shown that manipulating the calcium spike in the developing Xenopus larva can alter the number and specification of dopaminergic neurons in different brain regions. They altered the calcium spike by injecting constructs of the inward-rectifying potassium channel $\mathrm{K}_{\mathrm{ir}} 2.1$ or the sodium channel $\mathrm{Na}_{\mathrm{v}} 2 \mathrm{a} \alpha \beta$ into the embryos; this resulted in variable dopaminergic neuron expression depending upon the location. Soden et al. [73] showed that introduction of the human dominant-negative mutation hSK3 $\Delta$ into the gene coding for the calcium-activated small-conductance potassium channel KCNN3 $\left(\mathrm{K}_{\mathrm{Ca}} 2.3\right)$ changed the firing of mice dopamine neurons to a bursting instead of a tonic pattern. Mutant KCNN3 expression reduced the potassium current and increased the excitability of dopamine by increasing Ca levels, resulting in an elevated accumulation of dopamine and its metabolites. These mice exhibited heightened locomotion and deficits in sensory gating and attention, conditions which could be modeling mania and schizophrenia. Schiemann et al. [74] found that $\mathrm{K}_{\mathrm{ir}} 6.2$ (Kcnj11) knockout mice show reduced burst firing in medial substantia nigra dopamine neurons and a deficit in initiating novelty seeking in the open field test, which could be modeling behavior seen during depression. Calcium-dependent homeostatic regulatory mechanisms are essential for regulating the firing pattern of dopamine neurons depending upon sensory stimuli from the environment; any disruption would alter their firing rate [75]. There is substantial evidence that the firing pattern of dopaminergic neurons depends on the proper functioning of calcium and potassium channels. $K_{v}$ channels play an important role in regulating dopamine release. Martel et al. [76] have shown that studies using specific blockers in rat dorsal striatal brain slices provide evidence that the voltage-gated potassium channels $\mathrm{K}_{\mathrm{v}} 1.2$, 1.3 , and 1.6 play an important role in dopamine release.

It is interesting to speculate that the genetic load of SNPs in voltage-gated ion channels may result in an altered firing pattern of midbrain dopaminergic neurons starting from early development. This would result in altered dopaminergic tone, affecting connections in motivation and reward circuits. We suggest that calcium and potassium channels regulate the excitability of dopamine neurons, and that environmental triggers combined with dysfunctional ion channels might result in an increased dopaminergic tone during mania and a decreased dopaminergic tone during depression in $\mathrm{BD}$ patients. This might result in an endophenotype of abnormal motivational reward processing, leading to changes in motivation and risk-taking behaviors; environmental triggers might exaggerate those behaviors seen during mood episodes.

\section{Cognition}

BD patients exhibit neurocognitive deficits in multiple domains, including working memory, learning, attention, and executive functioning, both during mood episodes and in the euthymic state $[77,78]$. Neurocognitive
Balaraman/Lahiri/Nurnberger 
assessments of unaffected relatives of $\mathrm{BD}$ patients also showed cognitive deficits in verbal learning/memory and in the executive domain of response inhibition [79-81]. Meta-analyses of neurocognitive studies in unaffected relatives of $\mathrm{BD}$ patients demonstrated deficits in executive function and verbal memory $[82,83]$. Functional imaging studies in bipolar patients have looked for an association of genetic vulnerability to neurocognitive deficits. fMRI of healthy individuals carrying the CACNA1C risk variant rs 1006737 showed activation deficits in the bilateral hippocampus and anterior cingulate cortex during a cognitive task involving episodic memory recall [84].

The role of calcium and calcium channels in long-term potentiation (LTP) and synaptic plasticity has been well studied. Calcium influx through ion channels plays an important role in activity-dependent gene transcription, enabling organisms to adapt to different stimuli in the environment through synaptic plasticity, learning, and memory. LTCCs, given their location in the neuronal cell body and dendrites, regulate activity-dependent gene expression as they respond to depolarization currents [85, 86]. Ca influx through LTCCs regulates the phosphorylation of cAMP-responsive element-binding protein through the activation of calmodulin kinase (CAMK) and the Ras/mitogen-activated protein kinase (MAPK) signaling cascade [87-89]. The LTCC $\mathrm{Ca}_{\mathrm{v}} 1.2$ is critical for cellular events during the early development of the hippocampus [90]. LTCCs have been shown to be involved in synaptic plasticity and memory processes in the hippocampus. Mice lacking $\mathrm{Ca}_{\mathrm{v}} 1.2$ channels in the hippocampus and neocortex show an NMDA-independent loss of protein synthesis, as well as a defect in LTP and synaptic plasticity in the hippocampal region. These mice displayed deficits in learning and spatial memory in response to hippocampus-dependent behavioral tasks [91]. Brain-derived neurotropic factor (BDNF), which plays an important role in synaptic plasticity, is also regulated by LTCCs through the differential activation of BDNF promoters I and III [88, 92-94]. Postsynaptic secretion of BDNF and neurotrophin-3 is also dependent on calcium signaling through L-type calcium channels [95].

Many investigators have observed white matter microstructural abnormalities including hyperintensities in the deep white matter and subcortical gray matter in bipolar patients $[96,97]$. An impaired white matter connectivity between frontolimbic circuits and interhemispheric structures has been observed in BD patients [98-100]. Studies have also shown deficits in functional connectivity in the brain of bipolar subjects during cognitive tasks and in the resting state. fMRI of healthy individuals car-

Ion Channel Genes, BD and Specific Neurobiological Process Domains rying the $C A C N A 1 C$ risk variant rs1006737 demonstrated reduced functional coupling between the right and the left hippocampus during a cognitive task [84]. Postmortem brain studies of BD subjects have shown ultrastructural changes in oligodendrocytes, which are precursors of myelination in the CNS; these findings are suggestive of cell death in the prefrontal cortical region and reduced oligodendroglial density in Brodmann area 9 [101, 102]. There is evidence that intact LTCCs are important for oligodendrocyte cell lineage migration, differentiation, maturation, and myelination starting from early stages of development [103-105]. Voltage-gated potassium channels also seem to play an important role in oligodendrocyte maturation and myelination [106]. Dysfunctional ion channel signaling may also result in synaptic plasticity and myelination defects contributing to cognitive deficits, which might be exacerbated during mood episodes.

\section{Stress Response}

Patients with $\mathrm{BD}$ have trouble regulating their emotions during episodes and also display abnormal stress responses [107]. Small pilot neuroimaging studies have shown amygdala hyperactivation during emotional face reading in youth with $\mathrm{BD}$ or at risk of $\mathrm{BD}$; this may potentially be an endophenotype [108]. Resting-state functional connectivity MRI studies using blood oxygenation level-dependent signals have been helpful in identifying connectivity between distinct networks in the brain; one of these studies has demonstrated hyperconnectivity between the right amygdala and the right ventrolateral prefrontal cortex in euthymic BD subjects compared to healthy controls [109]. fMRI of BD subjects carrying the CACNA1C risk variant 1006737 displayed a significantly increased activation of the amygdala during a matching task of negative faces (expressing anger and fear) [110]. fMRI of healthy carriers and euthymic BD patients with risk-related variants at either CACNA1C rs1006737 or ANK3 rs10994336 during facial affect processing showed a reduction in connectivity between the visual and the ventral prefrontal cortical regions [111]. LTCCs also play an important role in the consolidation of fearful memories, by modulating LTP in the amygdala $[112,113]$. Voltage-gated calcium and potassium channels are also required for the modulation of the firing pattern of gonadotropin-releasing hormone neurons in the hypothalamus $[114,115]$. Rhythmic bursts of activity in anterior pituitary neurons are under the influence of voltage-gated calcium channels, and these bursts play a role in the intrinsic regulation of the hypothalamic-pituitary-adrenal axis (HPA) [116]. Altered fear responses and amygdala 
activation could well be due to disrupted connections between the prefrontal cortex and the limbic system, especially the amygdala [117]. Expected consequences of such changes might be a decreased ability to process complex tasks involving multiple brain regions. Such tasks might include accurate responses to emotionally charged stimuli, which have been shown to be impaired in BD patients $[107,118]$.

Genetic variants in voltage-gated ion channels might predispose $\mathrm{BD}$ patients to altered stress reactivity due to a dysfunctional HPA axis as well as impaired connectivity between the cortex and the limbic system due to myelination defects; environmental factors might further enhance the reaction to stress leading to further dysfunction.

\section{Circadian Rhythms}

Changes in sleep pattern are one of the major triggers for mood episodes in BD patients. Sleep disturbances, including an increased or a decreased need for sleep, an altered sleep/wake cycle, an altered REM onset latency, and difficulty falling asleep are seen not only during mood episodes but also during the euthymic state $[119,120]$; such changes are also found in those who are at high risk of developing BD [121]. Increased cholinergic sensitivity and REM density were noticed in remitted bipolar patients in response to the cholinergic drug arecoline [122]. A longer sleep onset latency and an altered REM onset latency are seen in both $\mathrm{BD}$ patients and at-risk relatives, and the latter may be the best candidates for an endophenotypic abnormality in the area of sleep [123].

Young subjects who are at high risk of affective disorder as well as euthymic BD patients showed an increased sensitivity to light suppression of melatonin, suggesting that this could be an endophenotype vulnerability marker in those patients [124-126]. Changes in 24-hour temperature and hormonal secretion have been noted in bipolar patients. BD patients have an increased nocturnal temperature and blunted thyroid-stimulating hormone secretion $[127,128]$. Clock $\Delta 19$ mutant mice show behaviors of increased locomotion, disrupted circadian rhythm, and decreased sensorimotor gating similar to mania [129].

The suprachiasmatic nucleus in the anterior hypothalamus is a major pacemaker that regulates circadian rhythms in the body; this nucleus receives information through the retinohypothalamic tract based on the amount of light stimulating retinal ganglion cells [130132]. Voltage-gated ion channels can modulate the firing pattern of suprachiasmatic nucleus neurons and retinal photoreceptors, thereby regulating their circadian rhythm. LTCCs also contribute to the depolarization of retinal photoreceptors regulating circadian rhythms through Ras-MAPK-CAMKII and PI3K-Akt signaling [133]. T-type calcium channels play an important role in the transition from high-frequency rhythms to slow oscillations in thalamocortical neurons during the initiation of sleep. Mice with mutations in the gene coding for the alpha $1 \mathrm{G}$ unit of the T-type calcium channel show alterations in sleep spindle rhythms in thalamocortical neurons resulting in decreased NREM sleep and increased sleep disturbance [134-137]. Mice that lack the alpha 1B subunit of the $\mathrm{N}$-type calcium channel $\mathrm{Ca}_{\mathrm{v}} 2.2$ show disturbances in vigilance state with increased consolidation in REM sleep and show an increased interval between NREM sleep and episodes of wakefulness [138].

Variant SNPs in voltage-gated ion channel genes may result in altered circadian rhythms and an altered firing pattern of pacemaker neurons; this might contribute to an endophenotype of delayed sleep onset. This is apart from the environmental trigger-dependent changes due to altered excitability, which may tend to exaggerate the sleep disturbances seen during mood episodes in $\mathrm{BD}$ patients.

\section{Energy and Metabolism}

Patients with $\mathrm{BD}$ experience a change in energy levels, with high energy during elevated mood and low energy during depressive periods, but there is also a subgroup of patients who may experience agitation during depressive episodes. Neurochemical measurements using proton magnetic resonance spectroscopy (MRS) show that ATP metabolite, myo-inositol, and lactate levels are altered in the brain regions of $\mathrm{BD}$ patients, indicating an altered energy metabolism and mitochondrial function not only during mood episodes but also in the euthymic state. An MRS study of BD patients demonstrated decreased lactate/Cr levels in both the posterior parieto-occipital and anterior cingulate cortices in the euthymic state [139]. An MRS study of BD subjects showed significantly lower adenosine diphosphate concentrations in the ventrolateral prefrontal cortex of euthymic subjects [140]. A prospective MRS study of offspring of parents with BD found a trend towards increased myo-inositol/Cr concentrations in the dorsolateral prefrontal cortex compared to controls [141]. Another study has shown reduced expression of $\mathrm{Na}-\mathrm{K}-\mathrm{ATP}$ ase in response to ethacrynic acid ionic stress challenges in lymphoblastoid cell lines of Old Order Amish $\mathrm{BD}$ subjects compared to control subjects within the same Amish pedigree [142]. Goldstein et al. [143] found evidence that SNPs in Na-K-ATPase alpha isoform 
Fig. 2. Endophenotypes to mood episodes.

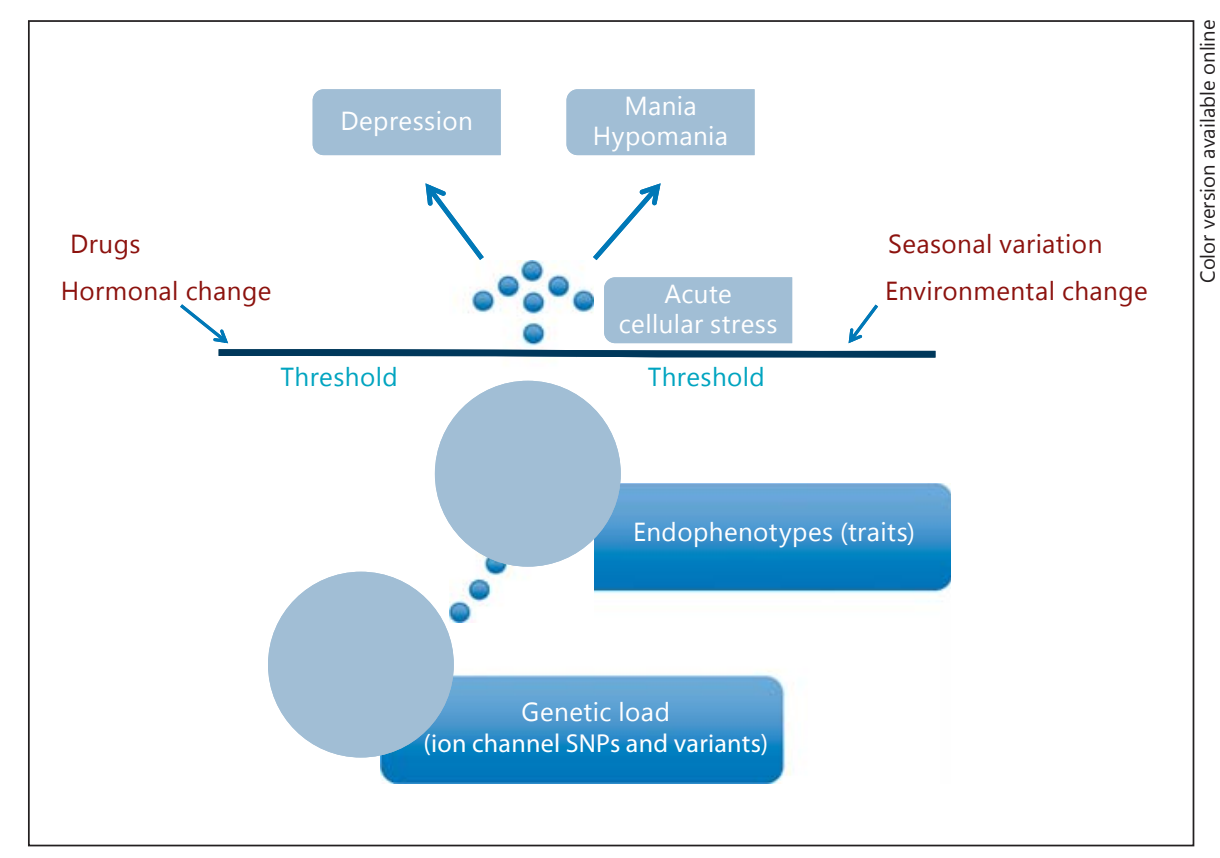

genes (ATP1A1-3) are significantly associated with $\mathrm{BD}$. The sodium-potassium pump (Na-K-ATPase) controls membrane excitability by exchanging $3 \mathrm{Na}$ ions for $2 \mathrm{~K}$ ions by hydrolysis of ATP [144]; dysregulation of Na-KATPase would alter the excitability of neurons along with the ATP/adenosine diphosphate balance. Transgenic mice with a mutation in Na-K-ATPase resulting in a reduced efficacy showed increased locomotion as well as reduced anxiety, exploratory behavior, and REM sleep latency behaviors similar to manic patients; cultured cortical neurons from these mutant mice also displayed increased calcium signaling [145]. An imbalance in ATP and myo-inositol shuttling would result in a change in energy production, metabolism, and expenditure. BD patients might have intrinsic deficits in energy production, expenditure, and metabolism due to SNPs in voltage-gated ion channels; these deficits may be further aggravated during mood episodes.

\section{How Are Endophenotypes Associated with a}

Predisposition to Mood Episodes?

BD patients experience frequent changes in mood, with elevated mood episodes of mania or low mood episodes of major depression. Irritability is also frequently seen in patients with $\mathrm{BD}$, particularly in mixed episodes [146]. Mood episodes do not generally manifest until adolescence or adulthood, although they can be seen in pediatric populations to a lesser extent.

Ion Channel Genes, BD and Specific Neurobiological Process Domains
We think that mood episodes are an acute and more magnified manifestation of neurobiological abnormalities underlying endophenotypes under environmental pressure. We propose that environmental triggers such as stress, drugs, seasonal variation, and hormonal and environmental changes, interacting with variants in ion channels, result in altered cellular signaling processes manifesting as mood episodes (fig. 2). Such changes may be mediated by the HPA axis or through the immune system. Treatment of mouse hippocampal slices with corticotropin-releasing hormone seems to alter neuronal excitability depending on L- and T-type calcium channels and also on voltage-gated potassium channels [147]. Antidepressants can alter neuronal excitability by altering calcium and potassium channels, acting as an environmental trigger for mood episodes [148, 149]. Astrocytes from mice treated with the antidepressant fluoxetine (10 $\mathrm{mg} / \mathrm{kg}$ ) for 2 weeks showed an increased expression of the calcium channel protein $\mathrm{Ca}_{\mathrm{v}} 1.2$ and an increased free cytosolic Ca ion concentration [150]. Seasonal changes can also act as an environmental trigger for mood episodes. Voltage-gated ion channel activity can show diurnal variation in the retina, suprachiasmatic nucleus neurons, and other neural tissues [133]. Immunofluorescence studies of chick cone photoreceptors have found that the expression of LTCCs is under circadian control, with more activation of these channels during the night [151]. Seasonal changes with variation in the amount of darkness and 
light during winter and summer may alter ion channel activity; this may be an adaptational advantage in the general population, but it may act as a trigger in BD patients.

\section{Discussion}

$\mathrm{BD}$ is a syndrome of complex symptoms with characteristic mood episodes of depression and mania or hypomania. In this paper, we have proposed a neurodevelopmental and environmental trigger model for how ion channel abnormalities may contribute to the bipolar phenome. The genetic load of multiple SNPs as well as structural and sequence variants in ion channels would contribute to an altered dopaminergic tone in impulse control and reward processing circuits, synaptic plasticity deficits, an altered HPA axis, myelination defects, circadian rhythm disturbances, and deficits in energy regulation. These developmental deficits alter the neural circuitry, resulting in endophenotypes of abnormal motivational reward processing, white matter hyperintensities, deficits in executive function, altered frontolimbic connectivity, aberrant amygdala activity, melatonin suppression, REM latency, and myo-inositol/ATP shuttling. The endophenotypes are associated with behaviors of poor impulse control, motivational changes, cognitive deficits, abnormal stress response, sleep disturbances, and energy changes. Then, environmental triggers such as stress, drugs, seasonal variation, and environmental and hormonal changes can affect the neurons acutely, altering cellular signaling processes and disturbing the homeostasis between neuronal excitation and inhibition through activity-dependent changes, resulting in full-blown clinical mood episodes (fig. 3). Repeated mood episodes will put the patients at risk of further mood cycling without environmental triggers. These environmental triggers could also modulate gene expression through epigenetic changes beginning in the early developmental phase but expressed phenotypically later in life; this type of environmentally mediated change in gene expression has been described by Lahiri et al. [152] in their LEARn (Latent Early-Life Associated Regulation) model.

The important question of how cycling between different mood states occurs in the same individual needs to be addressed. We propose here that the axon initial segment may be key to mood switching at the neuronal level. The axon initial segment, with a high cluster of sodium, potassium, and calcium channels, regulates the initiation of action potentials and generates electrical patterns in response to environmental input [153]. We think that genetic variations, resulting in structural or regulatory changes in ion channels in the axon initial segmental region, might be the basis for cellular changes that allow the triggering of mood cycling by external or internal stimuli.

The implication of altered ion channels in $\mathrm{BD}$ raises several interesting questions. What is the evidence for molecular changes in gene expression and protein levels of ion channel genes implicated in $\mathrm{BD}$, and do these changes occur in key areas, such as in dopaminergic neurons in ventral tegmental area or pacemaker neurons, or in executive control areas, such as the dorsolateral prefrontal cortex? These questions may be addressed at different levels. A microarray gene expression analysis of postmortem prefrontal cortices (Brodmann area 10) from bipolar subjects has shown a differential expression of calcium channel gene CACNA1A [154]. A meta-analysis of postmortem brain microarray gene expression studies of BD patients has demonstrated that the potassium channel genes $K C N A B 1$ and $K C N K 1$ are differentially regulated in BD [155]. Recently, a gene expression analysis using RNA sequencing from the dorsal prefrontal cortex of bipolar subjects showed that calcium channel genes (CACNA1C, CACNA1E, CACNA1G, CACNA1H, CACNA2D3, CACNB1, CACNB3, and CACNB4) and potassium channel genes (KCNA1-4, KCNAB1, KCNB1, KCNB2, KCNE3, KCNE4, KCNH1, KCNH2, KCNH5, KCNH7, KCNIP2, KCNIP4, KCNJ11, KCNJ12, KCNJ14, KCNK1, KCNK2, KCNK9, KCNK12, KCNMa1, KCNMB2, $K C N Q 2, K C N Q 3, K C N T 2$, and $K C N V 1$ ) are differentially expressed in bipolar individuals compared to controls [156]. Gene expression and protein levels in specific neuronal populations in postmortem brains from $\mathrm{BD}$ patients have not been studied well, and such studies could give us more specific information at the circuit level. It might be that gene expression, protein level, and modification state (e.g. the phosphorylation state of ion channel regulatory proteins including those that interact with ion channels, structural proteins that hold the ion channels, and cellular signaling proteins that alter the activation state of the ion channels) might play an important role in the pathogenesis of $\mathrm{BD}$.

This paper deals with neurobiological mechanisms underlying ion channel gene variants associated with $\mathrm{BD}$, since there is strong evidence for those genes in BD. However, there are other gene variants that may also play an important role in the pathogenesis of BD [157]. Though the calcium channels have also been associated with $\mathrm{BD}$, schizophrenia, major depression, attention deficit-hyperactivity disorder, and autism as a group, the strongest evidence exists for an association with $\mathrm{BD}$ as a single illness [5]. 


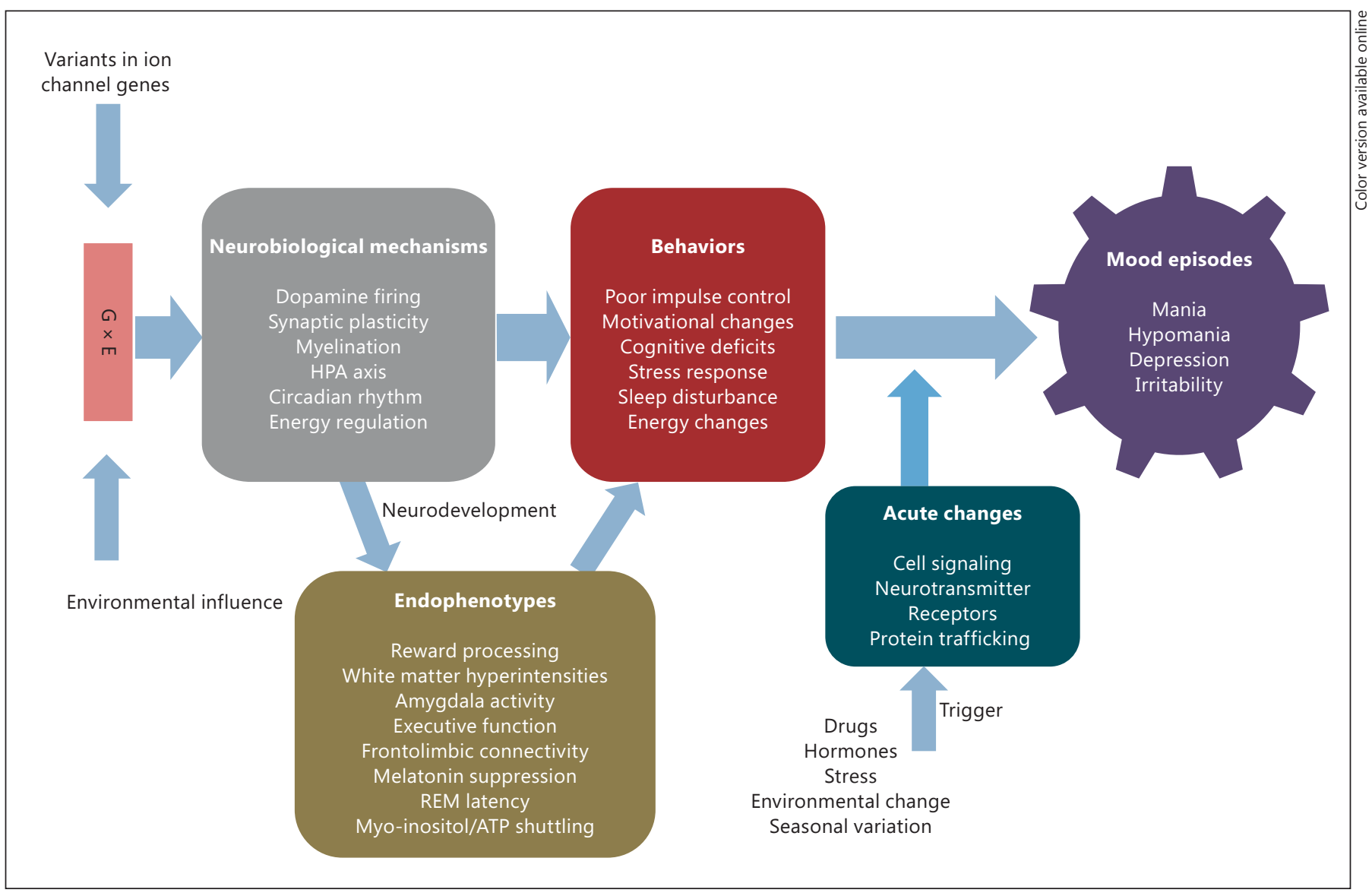

Fig. 3. Bipolar endophenotype-illness model.

\section{Future Directions}

$\mathrm{BD}$ research is hampered by a lack of appropriate animal models. It might be possible to introduce variants in calcium, $A N K 3$, and/or potassium channel genes into a rodent model using genome-editing technologies such as CRISPR [158-160], and one might then study subsequent alterations in neural circuitry. Such studies might further define the nature of BD-related endophenotypes and provide a model in which environmental triggers can reveal symptoms similar to those seen in $\mathrm{BD}$ patients during mood episodes. Longitudinal studies in adolescent offspring in high-risk BD families using clinical rating scales, cognitive tasks, functional imaging, and neurochemical studies would be needed to test this model. These studies could potentially result in identifying trait-dependent biomarkers. Understanding the pathophysiology of $\mathrm{BD}$ should lead to newer treatment modalities and new mood stabilizers.

Ion Channel Genes, BD and Specific

Neurobiological Process Domains

\section{Acknowledgements}

This work was partly supported by grants from the National Institutes of Health (NIH) and the Alzheimer's Association (Investigator-Initiated Research Grant) to D.K.L. J.I.N. was partly supported by NIH grant 1R01MH094483-01A1.

\section{Disclosure Statement}

D.K.L. serves on the scientific advisory boards of QR Pharma, Yuma Therapeutics, and Entia BioSciences as well as on the international advisory board of the Drug Discovery and Therapy World Congress; he holds stock options with QR Pharma and a patent involving memantine (the mode of action is not related to that of acamprosate); furthermore, he is Editor in Chief of Current Alzheimer Research; finally, he received Research Grant Support from Baxter Healthcare. The authors declare that they have no competing interests. 


\section{References}

1 Craddock N, Jones I: Genetics of bipolar disorder. J Med Genet 1999;36:585-594.

2 Askland K, Read C, Moore J: Pathways-based analyses of whole-genome association study data in bipolar disorder reveal genes mediating ion channel activity and synaptic neurotransmission. Hum Genet 2009;125:63-79.

3 Le-Niculescu H, Patel SD, Bhat M, Kuczenski R, Faraone SV, Tsuang MT, et al: Convergent functional genomics of genome-wide association data for bipolar disorder: comprehensive identification of candidate genes, pathways and mechanisms. Am J Med Genet B Neuropsychiatr Genet 2009;150B:155-181.

4 Nurnberger JI Jr, Koller DL, Jung J, Edenberg HJ, Foroud T, Guella I, et al: Identification of pathways for bipolar disorder: a meta-analysis. JAMA Psychiatry 2014;71:657-664.

5 Cross-Disorder Group of the Psychiatric Genomics Consortium: Identification of risk loci with shared effects on five major psychiatric disorders: a genome-wide analysis. Lancet 2013;381:1371-1379.

6 Nissen S, Liang S, Shehktman T, Kelsoe JR, Greenwood TA, Nievergelt CM, et al: Evidence for association of bipolar disorder to haplotypes in the 22q12.3 region near the genes stargazin, IFT27 and parvalbumin. Am J Med Genet B Neuropsychiatr Genet 2012; 159B:941-950.

7 Silberberg G, Levit A, Collier D, St Clair D, Munro J, Kerwin RW, et al: Stargazin involvement with bipolar disorder and response to lithium treatment. Pharmacogenet Genomics 2008;18:403-412.

8 Psychiatric GWAS Consortium Bipolar Disorder Working Group: Large-scale genomewide association analysis of bipolar disorder identifies a new susceptibility locus near ODZ4. Nat Genet 2011;43:977-983.

9 Smoller JW, Craddock N, Kendler K, Lee PH, Neale BM, Nurnberger JI, et al: Identification of risk loci with shared effects on five major psychiatric disorders: a genome-wide analysis. Lancet 2013;381:1371-1379.

10 Ferreira MA, O’Donovan MC, Meng YA Jones IR, Ruderfer DM, Jones L, et al: Collaborative genome-wide association analysis supports a role for $A N K 3$ and $C A C N A 1 C$ in bipolar disorder. Nat Genet 2008;40:10561058 .

11 Schulze TG, Detera-Wadleigh SD, Akula N, Gupta A, Kassem L, Steele J, et al: Two variants in Ankyrin 3 (ANK3) are independent genetic risk factors for bipolar disorder. Mol Psychiatry 2009; 14:487-491.

12 Scott LJ, Muglia P, Kong XQ, Guan W, Flickinger M, Upmanyu R, et al: Genome-wide association and meta-analysis of bipolar disorder in individuals of European ancestry. Proc Natl Acad Sci USA 2009;106:7501-7506.

13 Leussis MP, Madison JM, Petryshen TL: Ankyrin 3: genetic association with bipolar disorder and relevance to disease pathophysiology. Biol Mood Anxiety Disord 2012;2:18.
14 Zandi PP, Avramopoulos D, Willour VL, Huo Y, Miao K, Mackinnon DF, et al: SNP fine mapping of chromosome 8q24 in bipolar disorder. Am J Med Genet B Neuropsychiatr Genet 2007;144B:625-630.

15 Zhang P, Xiang N, Chen Y, Sliwerska E, McInnis MG, Burmeister M, et al: Family-based association analysis to finemap bipolar linkage peak on chromosome $8 \mathrm{q} 24$ using 2,500 genotyped SNPs and 15,000 imputed SNPs. Bipolar Disord 2010;12:786-792.

16 Borsotto M, Cavarec L, Bouillot M, Romey G, Macciardi F, Delaye A, et al: PP2A-B $\gamma$ subunit and $\mathrm{KCNQ} 2 \mathrm{~K}^{+}$channels in bipolar disorder. Pharmacogenomics J 2007;7:123-132.

17 Judy JT, Zandi PP: A review of potassium channels in bipolar disorder. Front Genet 2013;4:105.

18 Georgi B, Craig D, Kember RL, Liu W, Lindquist I, Nasser S, et al: Genomic view of bipolar disorder revealed by whole genome sequencing in a genetic isolate. PLoS Genet 2014;10:e1004229.

19 Psychiatric GWAS Consortium Bipolar Disorder Working Group: Large-scale genomewide association analysis of bipolar disorder identifies a new susceptibility locus near ODZ4. Nat Genet 2011;43:977-983.

20 Imbrici P, Camerino DC, Tricarico D: Major channels involved in neuropsychiatric disorders and therapeutic perspectives. Front Genet 2013;4:76.

21 Casamassima F, Hay AC, Benedetti A, Lattanzi L, Cassano GB, Perlis RH: L-type calcium channels and psychiatric disorders: a brief review. Am J Med Genet B Neuropsychiatr Genet 2010;153B:1373-1390.

22 Bhat S, Dao DT, Terrillion CE, Arad M, Smith RJ, Soldatov NM, et al: CACNA1C $\left(\mathrm{Ca}_{\mathrm{v}} 1.2\right)$ in the pathophysiology of psychiatric disease. Prog Neurobiol 2012;99:1-14.

23 McKinney BC, Sze W, Lee B, Murphy GG: Impaired long-term potentiation and enhanced neuronal excitability in the amygdala of $\mathrm{Ca}_{\mathrm{v}} 1.3$ knockout mice. Neurobiol Learn Mem 2009;92:519-528.

24 Shah M, Haylett DG: $\mathrm{Ca}^{2+}$ channels involved in the generation of the slow afterhyperpolarization in cultured rat hippocampal pyramidal neurons. J Neurophysiol 2000;83:25542561.

25 Pineda JC, Galarraga E, Foehring RC: Different $\mathrm{Ca}^{2+}$ source for slow AHP in completely adapting and repetitive firing pyramidal neurons. Neuroreport 1999;10:1951-1956.

26 Lima PA, Marrion NV: Mechanisms underlying activation of the slow AHP in rat hippocampal neurons. Brain Res 2007;1150:74-82.

27 Tzingounis AV, Nicoll RA: Contribution of KCNQ2 and KCNQ3 to the medium and slow afterhyperpolarization currents. Proc Natl Acad Sci USA 2008;105:19974-19979.

28 Catterall WA, Perez-Reyes E, Snutch TP, Striessnig J: International Union of Pharmacology. XLVIII. Nomenclature and structure- function relationships of voltage-gated calcium channels. Pharmacol Rev 2005;57:411425

29 Catterall WA: Structure and regulation of voltage-gated $\mathrm{Ca}^{2+}$ channels. Annu Rev Cell Dev Biol 2000;16:521-555.

30 Williams ME, Feldman DH, McCue AF, Brenner R, Velicelebi G, Ellis SB, et al: Structure and functional expression of alpha 1 , alpha 2, and beta subunits of a novel human neuronal calcium channel subtype. Neuron 1992;8:71-84.

31 Brust PF, Simerson S, McCue AF, Deal CR Schoonmaker S, Williams ME, et al: Human neuronal voltage-dependent calcium channels: studies on subunit structure and role in channel assembly. Neuropharmacology 1993; 32:1089-1102.

32 Lipscombe D, Helton TD, Xu W: L-type calcium channels: the low down. J Neurophysiol 2004;92:2633-2641.

33 Hell JW, Westenbroek RE, Warner C, Ahlijanian MK, Prystay W, Gilbert MM, et al: Identification and differential subcellular localization of the neuronal class $\mathrm{C}$ and class $\mathrm{D}$ L-type calcium channel alpha 1 subunits. J Cell Biol 1993;123:949-962.

34 Obermair GJ, Szabo Z, Bourinet E, Flucher BE: Differential targeting of the L-type $\mathrm{Ca}^{2+}$ channel alpha $1 \mathrm{C}\left(\mathrm{Ca}_{\mathrm{v}} 1.2\right)$ to synaptic and extrasynaptic compartments in hippocampal neurons. Eur J Neurosci 2004;19:2109-2122.

35 Leitch B, Szostek A, Lin R, Shevtsova O: Subcellular distribution of L-type calcium channel subtypes in rat hippocampal neurons. Neuroscience 2009;164:641-657.

36 Tottene A, Conti R, Fabbro A, Vecchia D, Shapovalova M, Santello M, et al: Enhanced excitatory transmission at cortical synapses as the basis for facilitated spreading depression in $\mathrm{Ca}_{\mathrm{v}} 2.1$ knockin migraine mice. Neuron 2009;61:762-773.

37 Vitko I, Shcheglovitov A, Baumgart JP, AriasOlguín II, Murbartián J, Arias JM, et al: Orientation of the calcium channel beta relative to the $\alpha_{1} 2.2$ subunit is critical for its regulation of channel activity. PLoS One 2008;3:e3560.

38 Taviaux S, Williams ME, Harpold MM, Nargeot J, Lory P: Assignment of human genes for beta 2 and beta 4 subunits of voltage-dependent $\mathrm{Ca}^{2+}$ channels to chromosomes 10p12 and 2q22-q23. Hum Genet 1997;100:151154.

39 Bichet D, Lecomte C, Sabatier JM, Felix R, De Waard M: Reversibility of the $\mathrm{Ca}^{2+}$ channel $\alpha_{1}-\beta$ subunit interaction. Biochem Biophys Res Commun 2000;277:729-735.

40 Bichet D, Cornet V, Geib S, Carlier E, Volsen $\mathrm{S}$, Hoshi T, et al: The I-II loop of the $\mathrm{Ca}^{2+}$ channel $\alpha_{1}$ subunit contains an endoplasmic reticulum retention signal antagonized by the $\beta$ subunit. Neuron 2000;25:177-190.

41 Buraei Z, Yang J: The $\beta$ subunit of voltagegated $\mathrm{Ca}^{2+}$ channels. Physiol Rev 2010;90: 1461-1506 
42 Burgess DL, Gefrides LA, Foreman PJ, Noebels JL: A cluster of three novel $\mathrm{Ca}^{2+}$ channel $\gamma$ subunit genes on chromosome 19q13.4: evolution and expression profile of the $\gamma$ subunit gene family. Genomics 2001;71:339-350.

43 Tomita S, Chen L, Kawasaki Y, Petralia RS, Wenthold RJ, Nicoll RA, et al: Functional studies and distribution define a family of transmembrane AMPA receptor regulatory proteins. J Cell Biol 2003;161:805-816.

44 Kordeli E, Lambert S, Bennett V: Ankyrin ${ }_{\mathrm{G}}$ : a new ankyrin gene with neural-specific isoforms localized at the axonal initial segment and node of Ranvier. J Biol Chem 1995;270: 2352-2359.

45 Srinivasan Y, Lewallen M, Angelides KJ: Mapping the binding site on ankyrin for the voltage-dependent sodium channel from brain. J Biol Chem 1992;267:7483-7489.

46 Zhou D, Lambert S, Malen PL, Carpenter S, Boland LM, Bennett V: Ankyrin $_{\mathrm{G}}$ is required for clustering of voltage-gated $\mathrm{Na}$ channels at axon initial segments and for normal action potential firing. J Cell Biol 1998;143:12951304.

47 Hedstrom KL, Xu X, Ogawa Y, Frischknecht R, Seidenbecher CI, Shrager P, et al: Neurofascin assembles a specialized extracellular matrix at the axon initial segment. J Cell Biol 2007;178:875-886.

48 Rasmussen HB, Frøkjaer-Jensen C, Jensen CS, Jensen HS, Jørgensen NK, Misonou H, et al: Requirement of subunit co-assembly and ankyrin-G for M-channel localization at the axon initial segment. J Cell Sci 2007;120(pt 6):953-963.

49 Sanchez-Ponce D, DeFelipe J, Garrido JJ, Munoz A: Developmental expression of $\mathrm{K}_{\mathrm{v}}$ potassium channels at the axon initial segment of cultured hippocampal neurons. PLoS One 2012;7:e48557.

50 Maljevic S, Lerche H: Potassium channels: a review of broadening therapeutic possibilities for neurological diseases. J Neurol 2013;260: 2201-2211.

51 Tinel N, Lauritzen I, Chouabe C, Lazdunski $\mathrm{M}$, Borsotto M: The KCNQ2 potassium channel: splice variants, functional and developmental expression. Brain localization and comparison with KCNQ3. FEBS Lett 1998; 438:171-176.

52 Wang HS, Pan Z, Shi W, Brown BS, Wymore RS, Cohen IS, et al: KCNQ2 and KCNQ3 potassium channel subunits: molecular correlates of the M-channel. Science 1998;282: 1890-1893.

53 Johnston J, Griffin SJ, Baker C, Skrzypiec A, Chernova $\mathrm{T}$, Forsythe ID: Initial segment $\mathrm{K}_{\mathrm{v}} 2.2$ channels mediate a slow delayed rectifier and maintain high frequency action potential firing in medial nucleus of the trapezoid body neurons. J Physiol 2008;586:34933509.

54 Kihira Y, Hermanstyne TO, Misonou H: Formation of heteromeric $\mathrm{K}_{\mathrm{v}} 2$ channels in mammalian brain neurons. J Biol Chem 2010;285: 15048-15055.
55 Einarsen K, Calloe K, Grunnet M, Olesen SP, Schmitt N: Functional properties of human neuronal $\mathrm{K}_{\mathrm{v}} 11$ channels. Pflugers Arch 2009; 458:689-700

56 Rieder RO, Gershon ES: Genetic strategies in biological psychiatry. Arch Gen Psychiatry 1978;35:866-873.

57 Gottesman II, Gould TD: The endophenotype concept in psychiatry: etymology and strategic intentions. Am J Psychiatry 2003;160: 636-645.

58 Lenox RH, Gould TD, Manji HK: Endophenotypes in bipolar disorder. Am J Med Genet 2002;114:391-406.

59 Hasler G: Evaluating endophenotypes for psychiatric disorders. Rev Bras Psiquiatr 2006;28:91-92.

60 Hasler G, Drevets WC, Gould TD, Gottesman II, Manji HK: Toward constructing an endophenotype strategy for bipolar disorders. Biol Psychiatry 2006;60:93-105.

61 Post RM, Kalivas P: Bipolar disorder and substance misuse: pathological and therapeutic implications of their comorbidity and crosssensitisation. Br J Psychiatry 2013;202:172176.

62 Swann AC, Lijffijt M, Lane SD, Steinberg JL, Moeller FG: Increased trait-like impulsivity and course of illness in bipolar disorder. Bipolar Disord 2009;11:280-288.

63 Strakowski SM, Fleck DE, DelBello MP, Adler CM, Shear PK, Kotwal R, et al: Impulsivity across the course of bipolar disorder. Bipolar Disord 2010;12:285-297.

64 Lombardo LE, Bearden CE, Barrett J, Brumbaugh MS, Pittman B, Frangou S, et al: Trait impulsivity as an endophenotype for bipolar I disorder. Bipolar Disord 2012;14:565-570.

65 Powers RL, Russo M, Mahon K, Brand J, Braga RJ, Malhotra AK, et al: Impulsivity in bipolar disorder: relationships with neurocognitive dysfunction and substance use history. Bipolar Disord 2013;15:876-884.

66 Trost S, Diekhof EK, Zvonik K, Lewandowski M, Usher J, Keil M, et al: Disturbed anterior prefrontal control of the mesolimbic reward system and increased impulsivity in bipolar disorder. Neuropsychopharmacology 2014; 39:1914-1923.

67 Pizzagalli DA, Goetz E, Ostacher M, Iosifescu DV, Perlis RH: Euthymic patients with bipolar disorder show decreased reward learning in a probabilistic reward task. Biol Psychiatry 2008;64:162-168.

68 Linke J, King AV, Rietschel M, Strohmaier J, Hennerici M, Gass A, et al: Increased medial orbitofrontal and amygdala activation: evidence for a systems-level endophenotype of bipolar I disorder. Am J Psychiatry 2012;169: 316-325.

69 Ballard IC, Murty VP, Carter RM, MacInnes JJ, Huettel SA, Adcock RA: Dorsolateral prefrontal cortex drives mesolimbic dopaminergic regions to initiate motivated behavior. J Neurosci 2011;31:10340-10346.

70 Lammel S, Lim BK, Malenka RC: Reward and aversion in a heterogeneous midbrain dopa- mine system. Neuropharmacology 2014; 76(pt B):351-359.

71 Ferrari DC, Mdzomba BJ, Dehorter N, Lopez C, Michel FJ, Libersat F, et al: Midbrain dopaminergic neurons generate calcium and sodium currents and release dopamine in the striatum of pups. Front Cell Neurosci 2012; 6:7.

72 Velazquez-Ulloa NA, Spitzer NC, Dulcis D: Contexts for dopamine specification by calcium spike activity in the CNS. J Neurosci 2011;31:78-88

73 Soden ME, Jones GL, Sanford CA, Chung AS, Guler AD, Chavkin C, et al: Disruption of dopamine neuron activity pattern regulation through selective expression of a human KCNN3 mutation. Neuron 2013;80:9971009.

74 Schiemann J, Schlaudraff F, Klose V, Bingmer M, Seino S, Magill PJ, et al: K-ATP channels in dopamine substantia nigra neurons control bursting and novelty-induced exploration. Nat Neurosci 2012;15:1272-1280.

75 Kim SH, Jang JY, Jang M, Um KB, Chung S, Kim HJ, et al: Homeostatic regulation mechanism of spontaneous firing determines glutamate responsiveness in the midbrain dopamine neurons. Cell Calcium 2013;54:295306.

76 Martel P, Leo D, Fulton S, Bérard M, Trudeau LE: Role of $\mathrm{K}_{\mathrm{v}} 1$ potassium channels in regulating dopamine release and presynaptic D2 receptor function. PLoS One 2011;6:e20402.

77 Vohringer PA, Barroilhet SA, Amerio A, Reale ML, Alvear K, Vergne D, et al: Cognitive impairment in bipolar disorder and schizophrenia: a systematic review. Front Psychiatry 2013;4:87.

78 Malhi GS, Ivanovski B, Hadzi-Pavlovic D, Mitchell PB, Vieta E, Sachdev P: Neuropsychological deficits and functional impairment in bipolar depression, hypomania and euthymia. Bipolar Disord 2007;9:114-125.

79 Quraishi S, Walshe M, McDonald C, Schulze K, Kravariti E, Bramon E, et al: Memory functioning in familial bipolar I disorder patients and their relatives. Bipolar Disord 2009;11: 209-214.

80 Schulze KK, Walshe M, Stahl D, Hall MH, Kravariti E, Morris R, et al: Executive functioning in familial bipolar I disorder patients and their unaffected relatives. Bipolar Disord 2011;13:208-216.

81 Bora E, Vahip S, Akdeniz F, Ilerisoy H, Aldemir E, Alkan M: Executive and verbal working memory dysfunction in first-degree relatives of patients with bipolar disorder. Psychiatry Res 2008;161:318-324.

82 Bora E, Yucel M, Pantelis C: Cognitive endophenotypes of bipolar disorder: a meta-analysis of neuropsychological deficits in euthymic patients and their first-degree relatives. J Affect Disord 2009;113:1-20.

83 Arts B, Jabben N, Krabbendam L, van Os J: Meta-analyses of cognitive functioning in euthymic bipolar patients and their first-degree relatives. Psychol Med 2008;38:771-785.
Ion Channel Genes, BD and Specific Neurobiological Process Domains
Mol Neuropsychiatry 2015;1:23-35 DOI: $10.1159 / 000371886$ 
84 Erk S, Meyer-Lindenberg A, Schnell K, Opitz von Boberfeld C, Esslinger C, Kirsch P, et al: Brain function in carriers of a genome-wide supported bipolar disorder variant. Arch Gen Psychiatry 2010;67:803-811.

85 Mermelstein PG, Bito H, Deisseroth K, Tsien RW: Critical dependence of cAMP response element-binding protein phosphorylation on L-type calcium channels supports a selective response to EPSPs in preference to action potentials. J Neurosci 2000;20:266-273.

86 Berridge MJ, Lipp P, Bootman MD: The versatility and universality of calcium signalling. Nat Rev Mol Cell Biol 2000;1:11-21.

87 Dolmetsch RE, Pajvani U, Fife K, Spotts JM, Greenberg ME: Signaling to the nucleus by an L-type calcium channel-calmodulin complex through the MAP kinase pathway. Science 2001;294:333-339.

88 Bito H, Deisseroth K, Tsien RW: CREB phosphorylation and dephosphorylation: a $\mathrm{Ca}^{2+}$ and stimulus duration-dependent switch for hippocampal gene expression. Cell 1996;87: 1203-1214.

89 Wu GY, Deisseroth K, Tsien RW: Activitydependent CREB phosphorylation: convergence of a fast, sensitive calmodulin kinase pathway and a slow, less sensitive mitogenactivated protein kinase pathway. Proc Natl Acad Sci USA 2001;98:2808-2813.

90 Kramer AA, Ingraham NE, Sharpe EJ, Mynlieff M: Levels of $\mathrm{Ca}_{V} 1.2 \mathrm{~L}$-type $\mathrm{Ca}^{2+}$ channels peak in the first two weeks in rat hippocampus whereas $\mathrm{Ca}_{\mathrm{V}} 1.3$ channels steadily increase through development. J Signal Transduct 2012;2012:597214.

91 Moosmang S, Haider N, Klugbauer N, Adelsberger $\mathrm{H}$, Langwieser $\mathrm{N}$, Muller J, et al: Role of hippocampal $\mathrm{Ca}_{\mathrm{v}} 1.2 \mathrm{Ca}^{2+}$ channels in NMDA receptor-independent synaptic plasticity and spatial memory. J Neurosci 2005;25: 9883-9892.

92 Tabuchi A, Nakaoka R, Amano K, Yukimine M, Andoh T, Kuraishi Y, et al: Differential activation of brain-derived neurotrophic factor gene promoters I and III by $\mathrm{Ca}^{2+}$ signals evoked via $\mathrm{L}$-type voltage-dependent and $\mathrm{N}$ methyl-D-aspartate receptor $\mathrm{Ca}^{2+}$ channels. J Biol Chem 2000;275:17269-17275.

93 Zheng F, Zhou X, Luo Y, Xiao H, Wayman G, Wang H: Regulation of brain-derived neurotrophic factor exon IV transcription through calcium responsive elements in cortical neurons. PLoS One 2011;6:e28441.

94 West AE, Chen WG, Dalva MB, Dolmetsch RE, Kornhauser JM, Shaywitz AJ, et al: Calcium regulation of neuronal gene expression. Proc Natl Acad Sci USA 2001;98:1102411031.

95 Kolarow R, Brigadski T, Lessmann V: Postsynaptic secretion of BDNF and NT-3 from hippocampal neurons depends on calcium calmodulin kinase II signaling and proceeds via delayed fusion pore opening. J Neurosci 2007;27:10350-10364.
96 Macritchie KA, Lloyd AJ, Bastin ME, Vasudev K, Gallagher P, Eyre R, et al: White matter microstructural abnormalities in euthymic bipolar disorder. Br J Psychiatry 2010;196:52-58

97 Beyer JL, Young R, Kuchibhatla M, Krishnan KR: Hyperintense MRI lesions in bipolar disorder: a meta-analysis and review. Int Rev Psychiatry 2009;21:394-409.

98 Townsend JD, Torrisi SJ, Lieberman MD, Sugar CA, Bookheimer SY, Altshuler LL: Frontal-amygdala connectivity alterations during emotion downregulation in bipolar I disorder. Biol Psychiatry 2013;73:127-135.

99 Torgerson CM, Irimia A, Leow AD, Bartzokis G, Moody TD, Jennings RG, et al: DTI tractography and white matter fiber tract characteristics in euthymic bipolar I patients and healthy control subjects. Brain Imaging Behav 2013;7:129-139.

100 Leow A, Ajilore O, Zhan L, Arienzo D, GadElkarim J, Zhang A, et al: Impaired inter-hemispheric integration in bipolar disorder revealed with brain network analyses. Biol Psychiatry 2013;73:183-193.

101 Uranova N, Orlovskaya D, Vikhreva O, Zimina I, Kolomeets N, Vostrikov V, et al: Electron microscopy of oligodendroglia in severe mental illness. Brain Res Bull 2001;55: 597-610.

102 Uranova NA, Vostrikov VM, Orlovskaya DD, Rachmanova VI: Oligodendroglial density in the prefrontal cortex in schizophrenia and mood disorders: a study from the Stanley Neuropathology Consortium. Schizophr Res 2004;67:269-275.

103 Paez PM, Fulton D, Colwell CS, Campagnoni AT: Voltage-operated $\mathrm{Ca}^{2+}$ and $\mathrm{Na}^{+}$channels in the oligodendrocyte lineage. J Neurosci Res 2009;87:3259-3266.

104 Paez PM, Fulton DJ, Spreuer V, Handley V, Campagnoni CW, Macklin WB, et al: Golli myelin basic proteins regulate oligodendroglial progenitor cell migration through voltage-gated $\mathrm{Ca}^{2+}$ influx. J Neurosci 2009; 29:6663-6676.

105 Fulton D, Paez PM, Fisher R, Handley V, Colwell CS, Campagnoni AT: Regulation of L-type $\mathrm{Ca}^{++}$currents and process morphology in white matter oligodendrocyte precursor cells by golli-myelin proteins. Glia 2010; 58:1292-1303

106 Tiwari-Woodruff S, Beltran-Parrazal L, Charles A, Keck T, Vu T, Bronstein J: $\mathrm{K}^{+}$ channel $\mathrm{K}_{\mathrm{V}} 3.1$ associates with $\mathrm{OSP} / \mathrm{clau}$ din-11 and regulates oligodendrocyte development. Am J Physiol Cell Physiol 2006; 291:C687-C698.

107 Townsend J, Altshuler LL: Emotion processing and regulation in bipolar disorder: a review. Bipolar Disord 2012;14:326-339.

108 Olsavsky AK, Brotman MA, Rutenberg JG, Muhrer EJ, Deveney CM, Fromm SJ, et al: Amygdala hyperactivation during face emotion processing in unaffected youth at risk for bipolar disorder. J Am Acad Child Adolesc Psychiatry 2012;51:294-303.
109 Torrisi S, Moody TD, Vizueta N, Thomason ME, Monti MM, Townsend JD, et al: Differences in resting corticolimbic functional connectivity in bipolar I euthymia. Bipolar Disord 2013;15:156-166.

110 Tesli M, Skatun KC, Ousdal OT, Brown AA, Thoresen C, Agartz I, et al: CACNA1C risk variant and amygdala activity in bipolar disorder, schizophrenia and healthy controls. PLoS One 2013;8:e56970.

111 Dima D, Jogia J, Collier D, Vassos E, Burdick KE, Frangou S: Independent modulation of engagement and connectivity of the facial network during affect processing by CACNA1C and ANK3 risk genes for bipolar disorder. JAMA Psychiatry 2013;70:13031311.

112 Bauer EP, Schafe GE, LeDoux JE: NMDA receptors and L-type voltage-gated calcium channels contribute to long-term potentiation and different components of fear memory formation in the lateral amygdala. J Neurosci 2002;22:5239-5249.

113 Weisskopf MG, Bauer EP, LeDoux JE: Ltype voltage-gated calcium channels mediate NMDA-independent associative longterm potentiation at thalamic input synapses to the amygdala. J Neurosci 1999;19:1051210519.

114 Chu Z, Tomaiuolo M, Bertram R, Moenter SM: Two types of burst firing in gonadotrophin-releasing hormone neurones. J Neuroendocrinol 2012;24:1065-1077.

115 Lee K, Duan W, Sneyd J, Herbison AE: Two slow calcium-activated afterhyperpolarization currents control burst firing dynamics in gonadotropin-releasing hormone neurons. J Neurosci 2010;30:6214-6224.

116 Bonnefont X, Fiekers J, Creff A, Mollard P: Rhythmic bursts of calcium transients in acute anterior pituitary slices. Endocrinology 2000;141:868-875

117 Karlsson KA, Windischberger C, Gerstl F, Mayr W, Siegel JM, Moser E: Modulation of hypothalamus and amygdalar activation levels with stimulus valence. Neuroimage 2010; 51:324-328

118 Phillips ML, Swartz HA: A critical appraisal of neuroimaging studies of bipolar disorder: toward a new conceptualization of underlying neural circuitry and a road map for future research. Am J Psychiatry 2014;171: 829-843.

119 Brill S, Penagaluri P, Roberts RJ, Gao Y, ElMallakh RS: Sleep disturbances in euthymic bipolar patients. Ann Clin Psychiatry 2011; 23:113-116.

120 Harvey AG: Sleep and circadian rhythms in bipolar disorder: seeking synchrony, harmony, and regulation. Am J Psychiatry 2008; $165: 820-829$

121 Ritter PS, Marx C, Lewtschenko N, Pfeiffer S, Leopold K, Bauer M, et al: The characteristics of sleep in patients with manifest bipolar disorder, subjects at high risk of developing the disease and healthy controls. J Neural Transm 2012;119:1173-1184. 
122 Sitaram N, Nurnberger JI Jr, Gershon ES, Gillin JC: Cholinergic regulation of mood and REM sleep: potential model and marker of vulnerability to affective disorder. Am J Psychiatry 1982;139:571-576.

$123 \mathrm{Ng} \mathrm{TH}$, Chung KF, Ho FY, Yeung WF, Yung KP, Lam TH: Sleep-wake disturbance in interepisode bipolar disorder and high-risk individuals: a systematic review and metaanalysis. Sleep Med Rev 2014, Epub ahead of print.

124 Nurnberger JI Jr, Adkins S, Lahiri DK, Mayeda A, Hu K, Lewy A, et al: Melatonin suppression by light in euthymic bipolar and unipolar patients. Arch Gen Psychiatry 2000;57:572-579.

125 Nurnberger JI Jr, Berrettini W, Tamarkin L, Hamovit J, Norton J, Gershon E: Supersensitivity to melatonin suppression by light in young people at high risk for affective disorder. A preliminary report. Neuropsychopharmacology 1988;1:217-223.

126 Lewy AJ, Nurnberger JI Jr, Wehr TA, Pack D, Becker LE, Powell RL, et al: Supersensitivity to light: possible trait marker for manicdepressive illness. Am J Psychiatry 1985;142: 725-727.

127 Souetre E, Salvati E, Wehr TA, Sack DA, Krebs B, Darcourt G: Twenty-four-hour profiles of body temperature and plasma TSH in bipolar patients during depression and during remission and in normal control subjects. Am J Psychiatry 1988;145:11331137.

128 Souetre E, Salvati E, Pringuey D, Krebs B, Plasse Y, Darcourt G: The circadian rhythm of plasma thyrotropin in depression and recovery. Chronobiol Int 1986;3:197-205.

129 van Enkhuizen J, Minassian A, Young JW: Further evidence for Clock $\Delta 19$ mice as a model for bipolar disorder mania using cross-species tests of exploration and sensorimotor gating. Behav Brain Res 2013;249: 44-54.

130 Turek FW: Circadian neural rhythms in mammals. Annu Rev Physiol 1985;47:4964.

131 Bell-Pedersen D, Cassone VM, Earnest DJ, Golden SS, Hardin PE, Thomas TL, et al: Circadian rhythms from multiple oscillators: lessons from diverse organisms. Nat Rev Genet 2005;6:544-556.

132 Berson DM, Dunn FA, Takao M: Phototransduction by retinal ganglion cells that set the circadian clock. Science 2002;295:10701073.

133 Ko GY, Shi L, Ko ML: Circadian regulation of ion channels and their functions. J Neurochem 2009;110:1150-1169.

134 Lee J, Shin HS: T-type calcium channels and thalamocortical rhythms in sleep: a perspective from studies of T-type calcium channel knockout mice. CNS Neurol Disord Drug Targets 2007;6:63-69.
135 Lee J, Kim D, Shin HS: Lack of delta waves and sleep disturbances during non-rapid eye movement sleep in mice lacking $\alpha l_{\mathrm{G}}$-subunit of T-type calcium channels. Proc Natl Acad Sci USA 2004;101:18195-18199.

136 Crunelli V, Cope DW, Hughes SW: Thalamic T-type $\mathrm{Ca}^{2+}$ channels and NREM sleep. Cell Calcium 2006;40:175-190.

137 Anderson MP, Mochizuki T, Xie J, Fischler W, Manger JP, Talley EM, et al: Thalamic $\mathrm{Ca}_{v} 3.1$ T-type $\mathrm{Ca}^{2+}$ channel plays a crucial role in stabilizing sleep. Proc Natl Acad Sci USA 2005; 102:1743-1748.

138 Beuckmann CT, Sinton CM, Miyamoto N, Ino $\mathrm{M}$, Yanagisawa $\mathrm{M}$ : $\mathrm{N}$-type calcium channel $\alpha_{1 \mathrm{~B}}$ subunit $\left(\mathrm{Ca}_{\mathrm{v}} 2.2\right)$ knock-out mice display hyperactivity and vigilance state differences. J Neurosci 2003;23:6793-6797.

139 Brady RO Jr, Cooper A, Jensen JE, Tandon N, Cohen B, Renshaw P, et al: A longitudinal pilot proton MRS investigation of the manic and euthymic states of bipolar disorder. Transl Psychiatry 2012;2:e160.

140 Weber WA, Dudley J, Lee JH, Strakowski SM, Adler CM, DelBello MP: A pilot study of alterations in high energy phosphoryl compounds and intracellular $\mathrm{pH}$ in unmedicated adolescents with bipolar disorder. J Affect Disord 2013;150:1109-1113.

141 Singh MK, Jo B, Adleman NE, Howe M, Bararpour L, Kelley RG, et al: Prospective neurochemical characterization of child offspring of parents with bipolar disorder. Psychiatry Res 2013;214:153-160.

142 Huff MO, Li XP, Ginns E, El-Mallakh RS: Effect of ethacrynic acid on the sodium- and potassium-activated adenosine triphosphatase activity and expression in Old Order Amish bipolar individuals. J Affect Disord 2010;123:303-307.

143 Goldstein I, Lerer E, Laiba E, Mallet J, Mujaheed $\mathrm{M}$, Laurent $\mathrm{C}$, et al: Association between sodium- and potassium-activated adenosine triphosphatase $\alpha$ isoforms and bipolar disorders. Biol Psychiatry 2009;65: 985-991.

144 Therien AG, Blostein R: Mechanisms of sodium pump regulation. Am J Physiol Cell Physiol 2000;279:C541-C566.

145 Kirshenbaum GS, Clapcote SJ, Duffy S, Burgess CR, Petersen J, Jarowek KJ, et al: Manialike behavior induced by genetic dysfunction of the neuron-specific $\mathrm{Na}^{+}, \mathrm{K}^{+}$-ATPase a3 sodium pump. Proc Natl Acad Sci USA 2011;108:18144-18149.

146 Iasevoli F, Valchera A, Di Giovambattista E, Marconi M, Rapagnani MP, De Berardis D, et al: Affective temperaments are associated with specific clusters of symptoms and psychopathology: a cross-sectional study on bipolar disorder inpatients in acute manic, mixed, or depressive relapse. J Affect Disord 2013;151:540-550.
147 Kratzer S, Mattusch C, Metzger MW, Dedic N, Noll-Hussong M, Kafitz KW, et al: Activation of $\mathrm{CRH}$ receptor type 1 expressed on glutamatergic neurons increases excitability of CA1 pyramidal neurons by the modulation of voltage-gated ion channels. Front Cell Neurosci 2013;7:91.

148 Yeung SY, Millar JA, Mathie A: Inhibition of neuronal $\mathrm{K}_{\mathrm{V}}$ potassium currents by the antidepressant drug, fluoxetine. Br J Pharmacol 1999;128:1609-1615.

149 Kobayashi T, Washiyama K, Ikeda K: Inhibition of $\mathrm{G}$ protein-activated inwardly rectifying $\mathrm{K}^{+}$channels by different classes of antidepressants. PLoS One 2011;6:e28208.

150 Du T, Liang C, Li B, Hertz L, Peng L: Chronic fluoxetine administration increases expression of the $\mathrm{L}$-channel gene $\mathrm{Ca}_{\mathrm{v}} 1.2$ in astrocytes from the brain of treated mice and in culture and augments $\mathrm{K}^{+}$-induced increase in $\left[\mathrm{Ca}^{2+}\right]_{\mathrm{i}}$. Cell Calcium 2014;55:166174.

151 Ko ML, Liu Y, Dryer SE, Ko GY: The expression of L-type voltage-gated calcium channels in retinal photoreceptors is under circadian control. J Neurochem 2007;103:784792.

152 Lahiri DK, Maloney B, Zawia NH: The LEARn model: an epigenetic explanation for idiopathic neurobiological diseases. Mol Psychiatry 2009; 14:992-1003.

153 Buffington SA, Rasband MN: The axon initial segment in nervous system disease and injury. Eur J Neurosci 2011;34:1609-1619.

154 Iwamoto K, Kakiuchi C, Bundo M, Ikeda K, Kato T: Molecular characterization of bipolar disorder by comparing gene expression profiles of postmortem brains of major mental disorders. Mol Psychiatry 2004;9:406416.

155 Elashoff M, Higgs BW, Yolken RH, Knable MB, Weis S, Webster MJ, et al: Meta-analysis of 12 genomic studies in bipolar disorder. J Mol Neurosci 2007;31:221-243.

156 Akula N, Barb J, Jiang X, Wendland JR, Choi $\mathrm{KH}$, Sen SK, et al: RNA-sequencing of the brain transcriptome implicates dysregulation of neuroplasticity, circadian rhythms and GTPase binding in bipolar disorder. Mol Psychiatry 2014;19:1179-1185.

157 Nurnberger JI Jr, Koller DL, Jung J, Edenberg HJ, Foroud T, Guella I, et al: Identification of pathways for bipolar disorder: a meta-analysis. JAMA Psychiatry 2014;71:657664.

158 Ran FA, Hsu PD, Wright J, Agarwala V, Scott DA, Zhang F: Genome engineering using the CRISPR-Cas9 system. Nat Protoc 2013;8:2281-2308.

159 Cong L, Ran FA, Cox D, Lin S, Barretto R, Habib N, et al: Multiplex genome engineering using CRISPR/Cas systems. Science 2013;339:819-823.

160 Aida T, Imahashi R, Tanaka K: Translating human genetics into mouse: the impact of ultra-rapid in vivo genome editing. Dev Growth Differ 2014;56:34-45.
Ion Channel Genes, BD and Specific Neurobiological Process Domains
Mol Neuropsychiatry 2015;1:23-35 DOI: $10.1159 / 000371886$ 